\title{
Planorbidae, Lymnaeidae and Physidae of Peru (Mollusca: Basommatophora)
}

\author{
W Lobato Paraense
}

Departamento de Malacologia, Instituto Oswaldo Cruz-Fiocruz, Av. Brasil 4365, 21045-900 Rio de Janeiro, RJ, Brasil

In the course of several trips to Peru I had the opportunity of collecting topotypic specimens of Biomphalaria andecola (Orbigny, 1835), B. helophila (Orbigny, 1835), B. pucaraensis (Preston, 1909), Drepanotrema limayanum (Lesson, 1830), D. kermatoides (Orbigny, 1835), and Lymnaea viatrix Orbigny, 1835, besides B. tenagophila (Orbigny, 1835), Helisoma trivolvis (Say, 1817), H. duryi (Wetherby, 1879), Physa acuta Draparnaud, 1801, and seemingly P. peruviana Gray, 1828.

B. pucaraensis is considered a junior synonym of B. peregrina (Orbigny, 1835).

Key words: Biomphalaria andecola - B. helophila - B. peregrina - B. pucaraensis - B. tenagophila Drepanotrema kermatoides - D. limayanum - Helisoma duryi - H. peruvianum - H. trivolvis - Lymnaea viatrix - Physa acuta P. peruviana - synonymy - Peru

This paper is based on material collected by the author during a trip supported by the National Research Council (CNPq) of Brazil, in 1956, and three others financed by the Pan American Health Organization in 1961, 1965 and 1972, and 14 samples collected by Dr Nicanor Ibañez, of the Universidad Nacional de Trujillo, Peru, in 1961-1964.

The snails were collected and treated as described elsewhere (Paraense 2003). Voucher specimens are deposited in the Malacological Collection of the Oswaldo Cruz Institute.

\section{Genus Helisoma Swainson, 1840}

Helisoma trivolvis (Say, 1817) - Ditch at Tembladera, Cajamarca Department, June 1962; ditch at Villa and creek at Puerto Chicama, Apr. 1965. All the specimens agree with Paraense's (1976b) description of H. trivolvis.

Helisoma peruvianum (Broderip, 1832) - The original description (not figured) hardly allows a sure recognition of this species:

Planorbis Peruvianus. Plan testâ discoideâ, pellucidâ, utrinque concavâ, anfract $\hat{s}$ basalis parte ultimâ subdepressâ; apertura subgibbâ, subdilatatâ: lat. 8/12, long. 4/12 poll.

Hab. In Peruviâ. (Malabriga, province of Truxillo.)

Found in a muddy pond nearly dried up. - W.J.B.

In a previous study (Paraense 1976b) I mentioned the occurrence of two species of Helisoma (H. trivolvis and Helisoma sp.) at Puerto Chicama (formerly Malabrigo). Unfortunately my intention to reexamine that material was frustrated by loss of the preserved soft parts. The probability of the alleged difference between the specimens being due to anatomical deformation for want of previous relaxation cannot be excluded.

H. peruvianum was redescribed by Orbigny (1835, 1837), who collected it at Callao and emphasized the facts

Fax:+55-21-2280.5840. E-mail: paraense@ioc.fiocruz.br Received 6 May 2003

Accepted 3 June 2003 that he found only empty shells in places that had been covered by the sea during the 1746 earthquake and that his searches in the surrounding area were unsuccessful. Baker (1945, Plate 141) figures shells of a specimen from Callao and another from "Brazil", the latter as a synonym of Planorbis moricandi Beck, 1837. By the way, $P$. moricandi is referred by Beck to Bahia, Brazil, where Helisoma does not occur.

Vivar et al. (1998) separate $H$. peruvianum from $H$. trivolvis by the shape of the preputial organ, ovoid in the former and cup-shaped in the latter. It should be noted, however, that the shape of that organ varies with the state of distension: in H. trivolvis it is egg-shaped when contracted within the preputial cavity and not infrequently when exserted, and cup-shaped when unfolded.

Helisoma duryi (Wetherby, 1879) - Santa Eulalia river, near its confluence with the Rimac, and ditch at Puente Piedra, Nov. 1956; ditches at Pachacamac and Pantanos de Villa, and creek at Puente Piedra, Nov. 1961; artificial pond at Botanical Garden, Lima, Apr. 1965; artificial pond at El Palomar, Lima, May 1965. The specimens agree, in shell and anatomy, to a previous description of $H$. duryi by Paraense (1976a).

\section{Genus Biomphalaria Preston, 1910}

Biomphalaria andecola (Orbigny, 1835) - Lake Umayo near Puno, Nov. 1952, collected by Dr Fortunato Blancas Sánchez. Shell and anatomy as in topotypes from Isla del Sol, Lake Titicaca, studied by Paraense and Deslandes (1957).

Biomphalaria helophila (Orbigny, 1835) - Ditch at Trujillo, June 1959; rivulet at Trujillo, Apr. 1963, studied by Paraense and Ibañez (1964); ditch at Trujillo, June 1963; ditch at Puerto Chicama, Apr. 1965; topotypes from marshes at Callao, Apr. 1965, studied by Paraense (1996).

Biomphalaria tenagophila (Orbigny, 1835) - Highly isolated population in Valle de Condebamba, Department of Cajamarca, June 1962, studied by Paraense et al. (1964), proving susceptible to infection with Schistosoma mansoni. 
Biomphalaria trigyra (Philippi, 1869) - Original description (not figured).

Biomphalaria pucaraensis (Preston, 1909) - Original description (poorly figured):

Planorbis pucaraensis, sp. n. (Fig. 15.)

Shell suborbicular, very depressed above, basally somewhat convex, brackish brown, spire slightly concave; whorls 4, rapidly increasing in size, sculptured with strong, transverse, arcuate lines of growth; sutures impressed; umbilicus moderately wide above, narrow and deep below; columella oblique, extending into a thin callus above; peristome simple, acute; aperture broadly sublunate.

Alt. 1.5, diam. maj. 6.75, diam. min. $5.5 \mathrm{~mm}$.

Aperture: alt. 2, diam. $2 \mathrm{~mm}$.

Hab. Pucara, Peru, at an altitude of 12,500 feet.

As far as I know, no subsequent mention has been made to this species, except in Harry's (1962) catalogue, in which it is placed in the "species group" of Taphius peregrinus (= Biomphalaria peregrina).

Our material was collected in Oct. 1972 from a grassy marsh by the road from Puno at the outskirts of Pucará. Additional samples were collected from ponds and brooks at Caracara, Juliaca and Calapuja.

The largest specimen from Pucará (Fig. 1A) is $9 \mathrm{~mm}$ in diameter, $4 \mathrm{~mm}$ in width at the aperture $(2.5 \mathrm{~mm}$ at the beginning of the outer whorl), and has 4.5 whorls. The shell is thin, sublustrous and subtranslucent, horncolored, with coarse growth lines intercalated between faint lines. The whorls increase rapidly in diameter, are flattened on the right side and markedly convex on the left, so that the right side is even and the left one is deeply umbilicate. The suture is well impressed on the right and deeply indented on the left. The periphery is rounded. The aperture is roundly sublunate, and about twice as wide as the beginning of the outer whorl. The peristome is thin and sharp. There is a distinct callus on the parietal wall.

The ventral membrane of the renal tube (Fig. 1B) is even and smooth, showing no renal ridge. In other features the renal region does not differ from that of other species of Biomphalaria. In all specimens the pulmonary cavity was heavily infested with Chaetogaster.

The reproductive system (Figs 1C-G) was observed on 20 dissected specimens from Pucará.

The ovotestis is composed of about 70 diverticula, most of which are unbranched. A minutely dissected ovotestis had 75 diverticula, of which 62 were simple, 11 bifurcate and 2 trifurcate. In another specimen with 74 diverticula, 62 were simple, 11 bifurcate and 1 trifurcate. The ovispermiduct and the seminal vesicles show no special characteristics, the latter varying in shape from knoblike to fingerlike.

The carrefour, oviduct, oviducal pouch, nidamental gland and uterus show no special characteristics. In many specimens the uterine wall has a granular appearance (Fig. 1E) due to infection with a species of Cryptobia, which may also produce the same condition in the spermatheca (Fig. 1F). The vagina is short and its ventral wall (in contact with the columellar muscle) shows a more or less protruding swelling, the vaginal pouch. The latter is frequently obscured by a pigmented fibrous membrane. The spermatheca varies in outline from club-shaped to egg-shaped, according to the amount of its contents. The spermathecal body is usually somewhat longer than the duct. The caudal part of the female duct (from the carrefour to the middle of the oviducal pouch) is shorter than the cephalic part (from the middle of the oviducal pouch to the vaginal opening). The spermiduct, longer than the oviduct to which it is adhered, follows a flexuous course. On emerging from the furrow of the oviducal pouch it gives off a row of prostatic diverticula, ranging from 8 to 13 , in most instances divided into primary and secondary branches. The foremost diverticula overlie to a variable extent the spermathecal body. The penis sheath, uniformly cylindric in shape, is about twice as wide as the widest portion of the vas deferens, and about half as wide and the same length as the prepuce. The penis (Fig. 1G), about as long as the penis sheath, is slender and tapers to a point where is the outlet of the penis canal.

In one of the larger specimens the radula had 137 transverse rows of teeth, with the formula 27-1-27 (7 laterals, 5 intermediates, 15 marginals). Radular teeth are shown in Fig. 1H.

Our largest specimen from Pucará exceeds Preston's by $3.25 \mathrm{~mm}$ in shell diameter, what may be attributed to size of the present sample ( 105 specimens).

Remark - This snail is anatomically indistinguishable from B. peregrina (for the latter, see Paraense and Deslandes 1958a, Paraense 1966), of which it is here considered a junior synonym.

\section{Genus Drepanotrema Fischer \& Crosse, 1880}

Drepanotrema limayanum (Lesson, 1830) - Topotypes from marshes at Callao, Nov. 1956, dealt with as $D$. paropseides (Orbigny, 1835) by Paraense and Deslandes (1958b). Additional specimens from ditches at Trujillo, June 1959, Callao, Nov. 1961 and Puerto Chicama, Apr. 1965. Shell and anatomy as in Paraense's (1976c) description and figures.

Drepanotrema kermatoides (Orbigny, 1835) Topotypes from marshes at Callao, Nov. 1956. Additional specimens from the same area, Nov. 1961, and Vila, Nov. 1956, Apr. 1965. Shell and anatomy as in Paraense \& Deslandes' (1958c) description. Additional specimens from ditches and creeks around Trujillo, Jun. 1959, Aug. 1961, Apr. 1963; from marshes at Puerto Chicama and Pimentel, Apr. 1965.

\section{Genus Lymnaea Lamarck, 1799}

Lymnaea viatrix Orbigny, 1835 - Santa Eulalia river, Lima, Nov. 1956; ponds at Pachacamac and Lima, Nov. 1961; rice paddy at Pimentel, pond at Vitarte, May 1965; pond at Pimentel, June 1965. Shell and anatomy as in Paraense (1976d).

\section{Genus Physa Draparnaud, 1801}

Physa acuta Draparnaud, 1805 - Marsh and ditches at Callao, near Rimac river, Nov. 1956, May 1965; ditch at Pachacamac, Lurin Valley, and Lima, Chillon Valley, Nov. 1961; pond at Puerto Chicama, rivulet at Pimentel, Apr. 1965. 

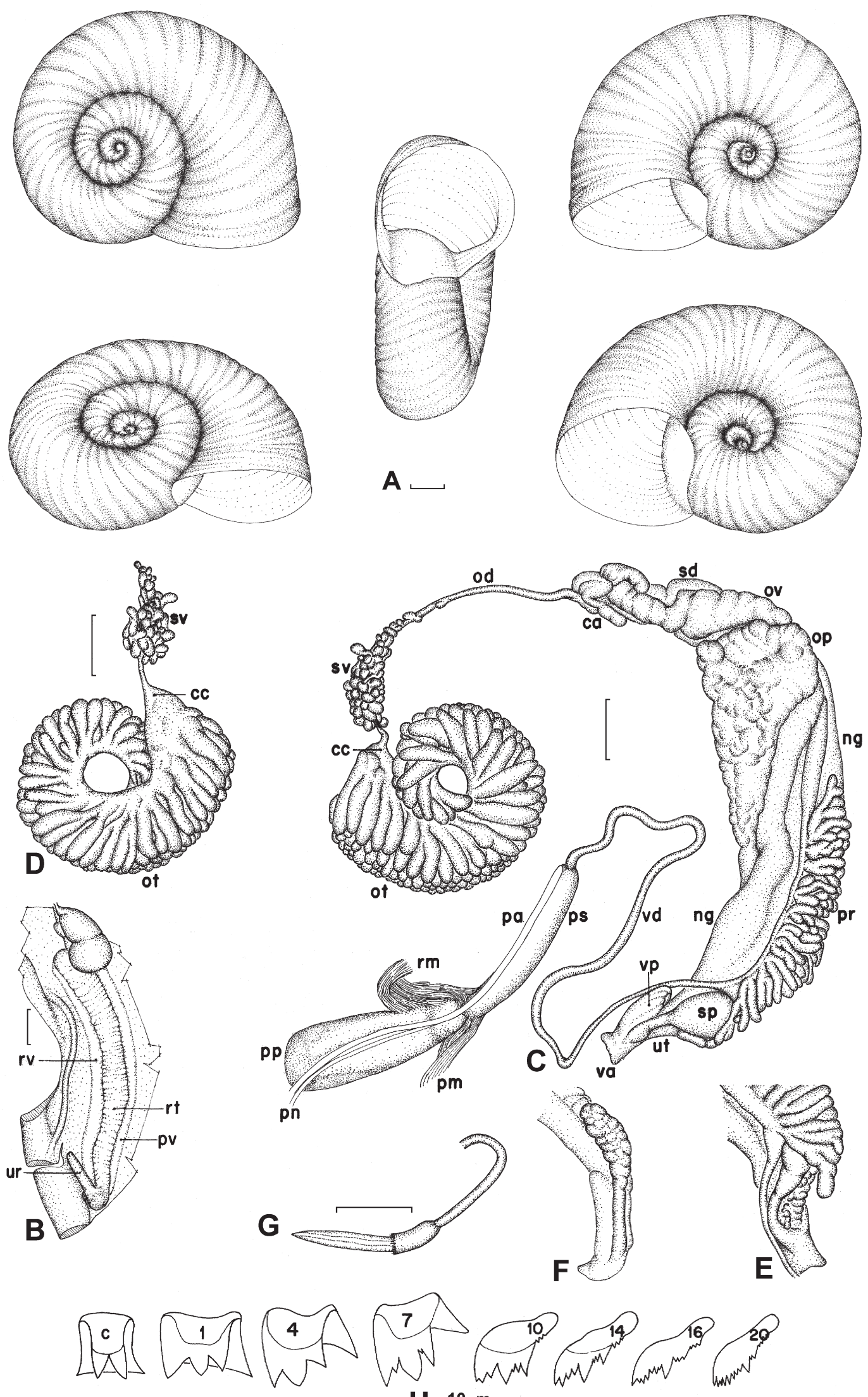

\section{H $10 \mu \mathrm{m}$}

Fig. 1: Biomphalaria pucaraensis $(=$ B. peregrina $)$ - A: shell; B: renal region; C-D: reproductive system; E: uterine; F: spermathecal infection with Cryptobia; G: penis (penis sheath removed); H: radular teeth $(\mathrm{C}=$ central; 1, $4=$ laterals; $7,10=$ intermediates; 14 , 16, 20 $=$ marginals. Bar $=1 \mathrm{~mm}$ (unless otherwise stated). 

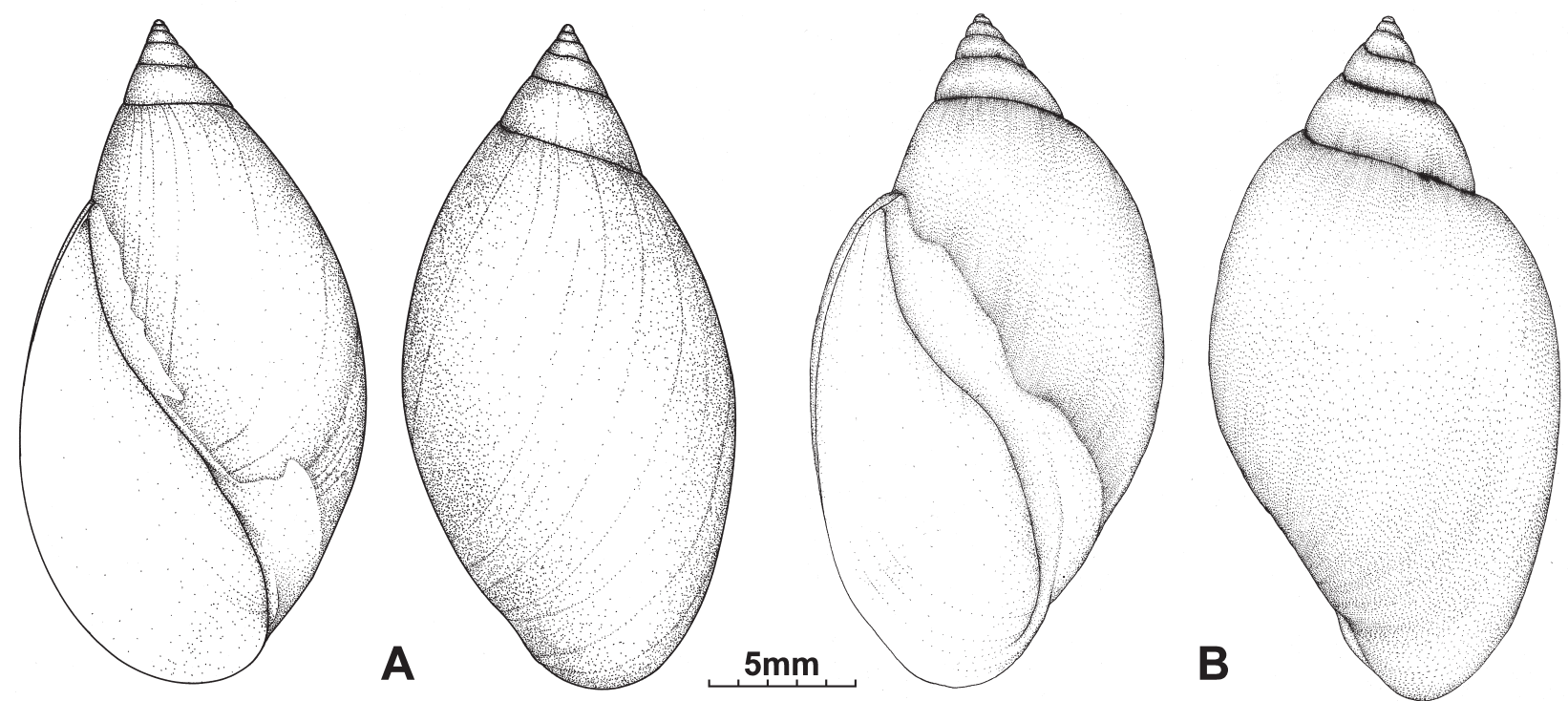

Fig. 2 - A: syntype of Physa peruviana Gray from Natural History Museum, London; B: Physa sp. (peruviana?) from Trujillo.

Remark - Physa acuta is considered a senior synonym of P. cubensis Pfeiffer, 1839 (see Paraense \& Pointier 2003).

?Physa peruviana Gray, 1828 - Original description:

Physa Peruviana, $n$. - Testâ ovatâ, spirâ acutâ; anfractibus 5 subito majoribus, convexiusculis; aperturâ spirâ triplo longiore; labio interiore supra ultimum anfractum subreflexo Icon. t. 6.f. 10 .

Inhab. Swamps between Lima and Callao, Rev. Hennah.

Shell ovate; spire acute; whorls 5 , rapidly enlarging, rather convex; mouth $3 / 4$ the length of the shell; inner lip slightly reflexed over the last whorl. Axis 1 , diameter $1 / 2$ an inch. Very like Bulla rivalis, Maton; but twice the size, and more ventricose.

In the course of three searches between Lima and Callao (Nov. 1956, Nov. 1961, Apr. 1965) I was unable to find any physid over $12 \mathrm{~mm}(1 / 2$ an inch) in shell length, and all the samples were anatomically indistinguishable from $P$. acuta. Three specimens from "Balneario Las Delicias", Trujillo, collected by Dr Nicanor Ibañez, were sent alive and decomposed en route. In shell characters (Fig. 2B) they answered to Gray's description and figure of P. peruviana (compare with Fig. 2A, from a syntype deposited in the malacological collection of the Natural History Museum, London).

\section{ACKNOWLEDGEMENTS}

To Mr Fred Naggs of the Department of Zoology, Natural History Museum, London, for the loan of a syntype of Physa peruviana, and to Mr J Eduardo Prado, artist of this Department, for preparing the figures.

\section{ABBREVIATIONS IN FIGURES}

ca: carrefour; cc: collecting canal of ovotestis; ng: nidamental gland; od: ovispermiduct; op: oviducal pouch; ot: ovotestis; ov: oviduct; pa: penial artery; pm: protractor muscle of penial complex; pn: penial nerve; pp: prepuce; pr: prostate; ps: penis sheath; pv: pulmonary vein; rm: retractor muscle of penial complex; rt: renal tube; rv: renal vein; sd: spermiduct; sp: spermatheca; sv: seminal vesicles; ur: ureter; ut: uterus; va: vagina; vd: vas deferens; vp: vaginal pouch.

\section{REFERENCES}

Baker FC 1945. The Molluscan Family Planorbidae, Univ Illinois Press, Urbana, 530 pp.

Broderip WJB 1832. Characters of new species of Mollusca and Conchifera, collected by Mr. Cuming. Proc Zool Soc London, Part 2: 124-126.

Draparnaud JPR 1805. Histoire Naturelle des Mollusques Terrestres et Fluviatiles de la France, D Colas, Paris.

Gray JE 1828. Spicilegia Zoologica; or original figures and short systematic descriptions of new and unfigured animals. Part I. Treüttel, Würtz, London? 8 pp.

Harry HW 1962. A critical catalogue of the nominal genera and species of Neotropical Planorbidae. Malacologia 1: 33-53.

Lesson RP 1830. Zoologie. T. 2, Part 1 (Mollusques : 239448). In LI Duperrey, Voyage Autour du Monde, Éxécuté par Ordre du Roi, sur la Corvette de Sa Majesté, La Coquille Pendant les Années 1822, 1823, 1824 et 1825, A Bertrand, Paris.

Orbigny A 1835. Synopsis terrestrium et fluviatilium molluscorum, in suo per Americam meridionalem itinere, ab A.D'Orbigny, collectorum. Mag Zool 5, Classe 5 (6162): $1-44$.

Orbigny A 1837. Voyage dans l'Amérique Méridionale, Mollusques 5 (3), P Bertrand, Paris.

Paraense WL 1966. The synonymy and distribution of Biomphalaria peregrina in the Neotropical region. Rev Brasil Biol 26: 269-296.

Paraense WL 1976a. A natural population of Helisoma duryi in Brazil. Malacologia 15:369-376.

Paraense WL 1976b. Helisoma trivolvis and some of its synonyms in the Neotropical region. Rev Brasil Biol 36: 187-204.

Paraense WL 1976c. Drepanotrema limayanum (Lesson, 1830) (Mollusca: Planorbidae). Rev Brasil Biol 36: 217-221. 
Paraense WL 1976d. Lymnaea viatrix: a study of topotypic specimens (Mollusca: Lymnaeidae). Rev Brasil Biol 36: 419428.

Paraense WL 1996. Neotropical planorbid snails with apertural lamellae. I. Biomphalaria helophila (Orbigny, 1835). Mem Inst Oswaldo Cruz 91: 177-186.

Paraense WL, Deslandes N 1957. A redescription of Taphius andecolus (Orbigny, 1835) (Pulmonata: Planorbidae). Rev Brasil Biol 17: 235-243.

Paraense WL, Deslandes N 1958a. Note sur Drepanotrema anatinum et Taphius peregrinus. J Conchyliol 98: 152-162.

Paraense WL, Deslandes N 1958b. Drepanotrema paropseides (Planorbidae). Nautilus 72: 37-41.

Paraense WL, Deslandes N 1958c. The Brazilian species of Drepanotrema. VI. D. kermatoides (Orbigny, 1835). Rev Brasil Biol 18: 293-299.
Paraense WL, Ibañez N 1964. Australorbis helophilus (Pulmonata: Planorbidae). Rev Brasil Biol 24: 249-258.

Paraense WL, Ibañez N, Miranda H 1964. Australorbis tenagophilus in Peru, and its susceptibility to Schistosoma mansoni. Am J Trop Med Hyg 13: 534-540.

Paraense WL, Pointier JP 2003. Physa acuta Draparnaud, 1805 (Gastropoda: Physidae): a study of topotypic specimens. Mem Inst Oswaldo Cruz 98: 513-517.

Preston HB 1909. New land, freshwater, and marine shells from South América. Ann Magaz Nat Hist 3 (8th Ser.): 507513.

Vivar R, Ramírez R, Huamán P 1998. Moluscos de los pantanos de Villa y su aporte a la conservación. In A Cano, KR Young (eds), Los Pantanos de Villa, Biologia y Conservación. Universidad Nacional Mayor de San Marcos, Museo de Historia Natural, Lima, Peru, p. 55-73. 